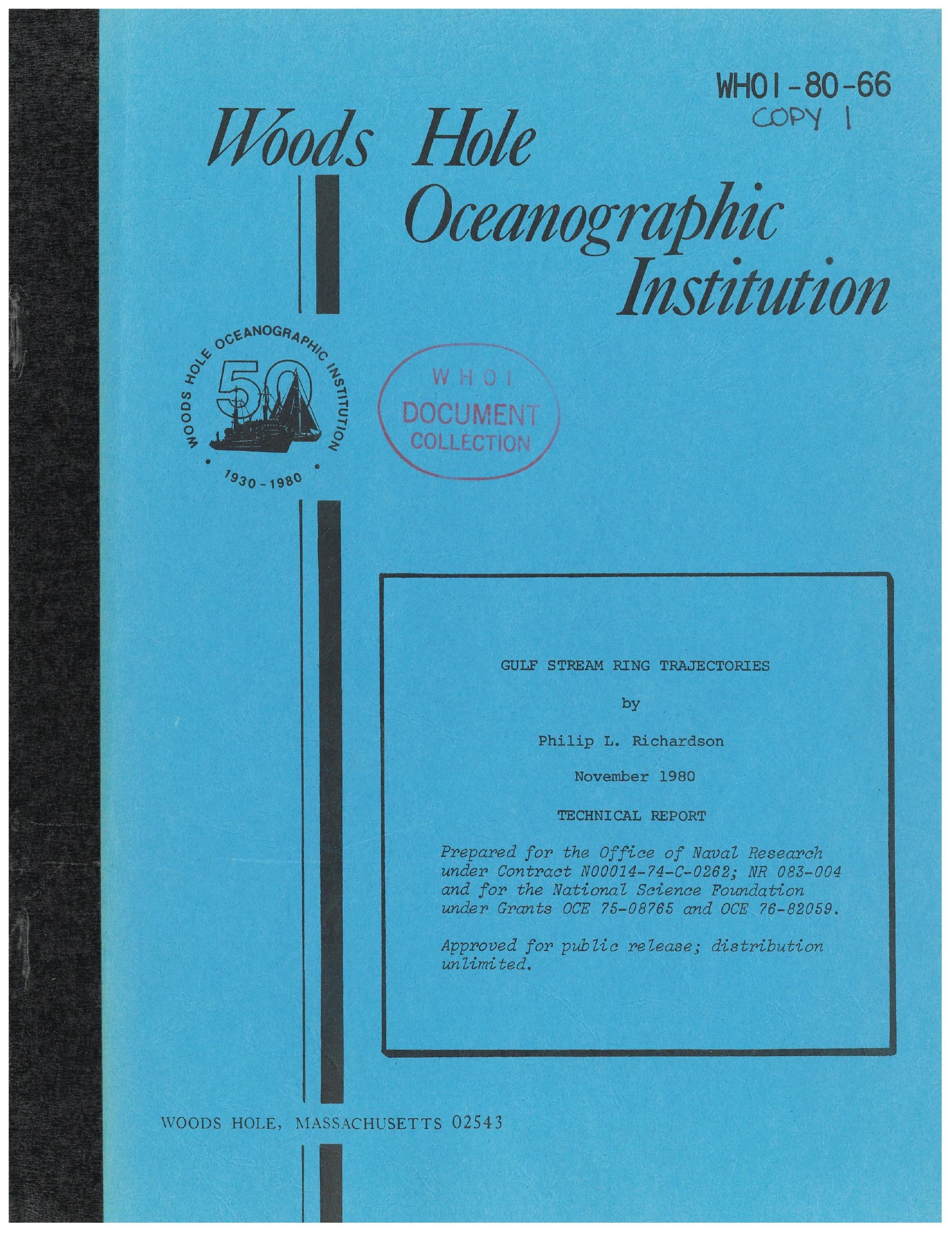




$$
\text { WHOI }-80-66
$$

GULF STREAM RING TRAJECTORIES

by

Philip L. Richardson

WOODS HOLE OCEANOGRAPHIC INSTITUTION

Woods Hole, Massachusetts 02543

November 1980

TECHNICAI REPORT

Prepared for the Office of Naval Research under Contract N00014-74-C-0262; NR 083-004 and for the National Science Foundation under Grants OCE 75-08765 and OCE 76-82059.

Reproduction in whole or in part is permitted for any purpose of the United States Govemment. In citing this report in a bibliography, the reference given should be to the "Joumal of Physical Oceanography, Vol. 10, No. 1, January 1980, pp. 90-104".

Approved for public release; distribution unlimited.

Approved for Distribution: Valentine Worthington, Chairman Department of Physical Oceanography 
Reprinted from Journal of Phystcal Oceanography, Vol. 10, No. 1, January 1980

American Meteorological Society

Printed in U. S. A.

\section{Gulf Stream Ring Trajectories}

PHILIP L. RICHARDSON 


\title{
Gulf Stream Ring Trajectories ${ }^{1}$
}

\author{
PHILIP L. RICHARDSON ${ }^{2}$ \\ Woods Hole Oceanographic Institution, Woods Hole, MA 02543
}

(Manuscript received 27 March 1979, in final form 13 August 1979)

\begin{abstract}
During the period 1976-78, the movement of 14 Gulf Stream rings, including two anticyclonic and 12 cyclonic rings, was measured with satellite-tracked free-drifting buoys. The buoys in the cyclonic rings showed a tendency to move out toward the high-velocity region of the ring and to remain there rotation the center. One buoy stayed in a ring as long as 8 months and completed 86 loops. Periods of rotation ranged from less than 2 days up to 10 days. The movement of the rings was complicated and appears to be related to the Gulf Stream and strong topographic features such as the New England Seamounts. Rings that were not touching the Stream generally moved westward with typical speeds of $5 \mathrm{~cm} \mathrm{~s}^{-1}$. Rings that were attached to the Stream generally moved downstream in the Stream with speeds up to $75 \mathrm{~cm} \mathrm{~s}^{-1}$. Frequently rings coalesced with the Gulf Stream and one of the following three things seemed to happen: 1) the ring turned into an open meander of the Stream and was lost; 2) the ring was advected rapidly downstream in the Stream and was presumably lost; and 3) the ring became attached to the Gulf Stream and then split off again as a modified ring. The results of this study, that frequently strong interactions occur between rings and the Gulf Stream, are in contrast to my original view that rings slowly translate southwestward through the Sargasso Sea and gradually decay there.
\end{abstract}

\section{Introduction}

It has been clear for some time that Gulf Stream rings occur frequently in the northwestern Atlantic, that they are of primary importance to that region, and that they greatly influence the size and shape of the Gulf Stream system. Yet due to the difficulty in following rings, their life histories and trajectories in the ocean have remained largely unknown. Only once has a ring been continuously and unambiguously followed for as long as 6 months; this was accomplished in 1967 by Fuglister (1977) using surface buoys, ships and an airplane. When the recently developed and relatively inexpensive satellitetracked buoy became available in 1975, we tried using one to remotely track a ring (Richardson et al., 1977). The results were sufficiently successful that during 1976 and 1977, several investigators began a cooperative and interdisciplinary experiment to study rings using free-drifting buoys to track them. Repeated cruises to the rings enabled us to measure their physical, chemical and biological characteristics and their changes with time.

This report is primarily a description of one aspect of the study - the free-drifting buoy experiment. The objective was to continuously follow rings in

\footnotetext{
${ }^{1}$ Contribution No. 4317 from the Woods Hole Oceanographic Institution and No. 112 from the Mid-Ocean Dynamics Experiment (POLYMODE).

${ }^{2}$ Presently visiting the Laboratoire d'Océanographie Physique, Muséum National d'Histoire Naturelle, Paris, France.

order to learn where they go, what their eventual fate is and what influences their motion. Although life histories of the two rings that we studied, Allen and Bob, were found to be very complicated, when these histories are combined with measurements of several other rings, we begin to see distinctive patterns. In order to illustrate these patterns and to show the complex series of events that can occur, a description of Bob's life will be given. ${ }^{3}$ This description will be followed by a summary of the movement of all the rings.

\section{The buoy}

The buoys that we used were made by Polar Research Laboratory, had a life of 9-12 months and carried temperature and drogue tension sensors. The buoys were tracked by the Nimbus F satellite; fixes were computed by NASA from the Doppler-shifted radio signal received by the satellite. Typically two good fixes per day were obtained for each buoy; fix errors were usually within $1-2 \mathrm{~km}$.

Two types of drogues were used. One consisted of a $200 \mathrm{~m}$ section of $3.8 \mathrm{~cm}$ diameter polypropylene line with a window-shade drogue $\left(25 \mathrm{~m}^{2}\right)$ attached to the bottom (buoy 731). The second consisted of the same line with a $25 \mathrm{~kg}$ weight attached to

\footnotetext{
${ }^{3}$ A description of the first ring (Allen) studied by the ring's group has been presented by Hagan et al. (1978) and by Richardson et al. (1979a).
} 
the end (buoys 512 and 614). Because of drogue sensor failures (overloading) the usual life of the drogues remains unknown, but the drogues probably remained attached to the buoys for at least several months. A more complete description of the buoys, fixes, data processing and individual buoy trajectories, velocities and temperatures is given by Richardson et al. (1979b).

\section{Ring Bob (1977)}

The second ring (Bob) studied by the ring group was a remarkable ring in several respects; when we sailed into it in April 1977 on Knorr cruise 65, we could see, feel and smell the presence of the ring's Slope Water core from the deck of the ship. Immediately on entering the central part we noticed a seaweed smell, similar to that of a seashore on a summer day. The water was obviously green and turbid as compared to the clear and deep blue of the
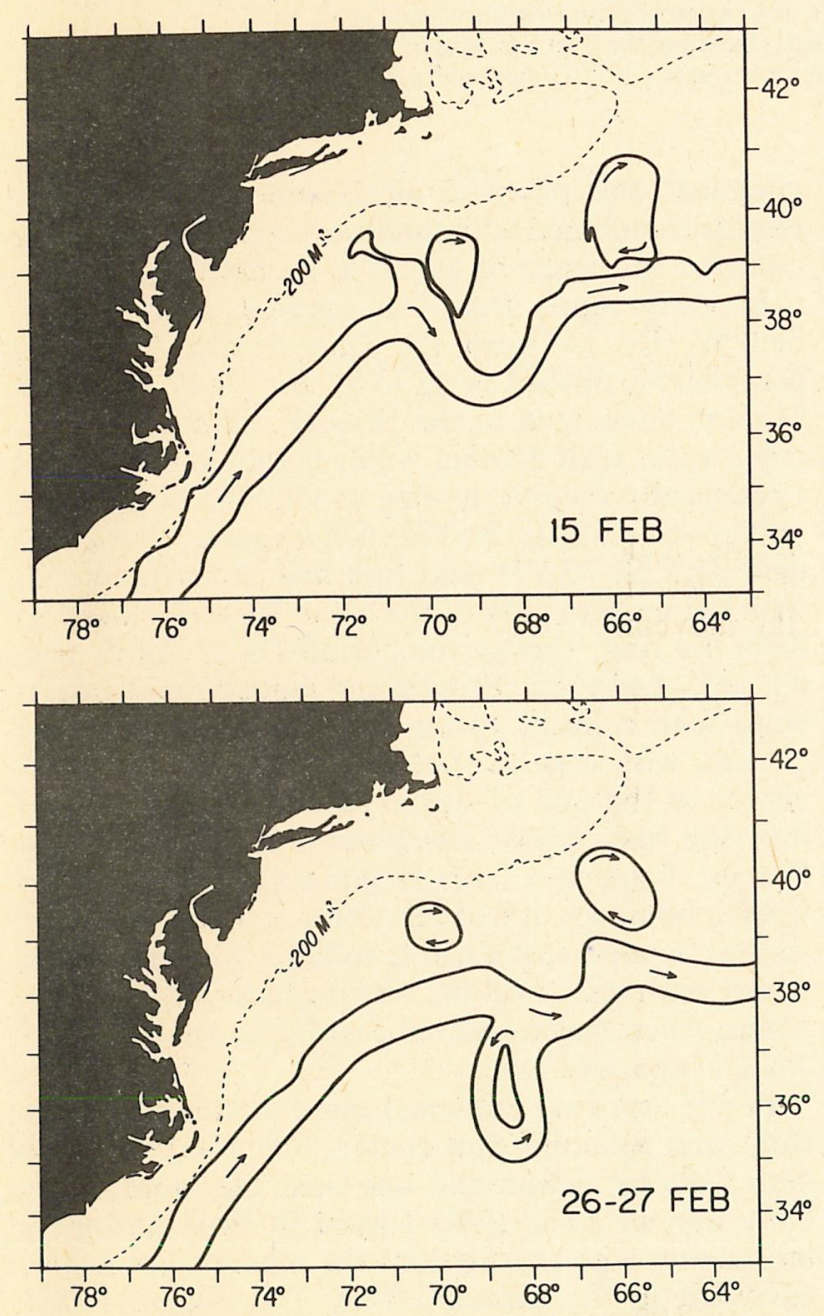

FIG. 1a. Schematic diagram showing formation of Gulf Stream ring Bob, February-March 1977, based on infrared images from the NOAA 5 satellite. Two anticyclonic rings were observed north of the Gulf Stream. nearby Gulf Stream and Sargasso Sea. The temperature of the surface water in the center was $15^{\circ} \mathrm{C}$, nearly $10^{\circ} \mathrm{C}$ colder than the surrounding water; this difference was reflected in the air temperature.

Probably the most remarkable aspect of the 1977 study of Bob was that we obtained an excellent series of data covering all stages of Bob's life, from birth to death. The data set is both a result of our planning and skill during the program as well as some luck. Bob's life consisted of four main stages which were the following: its formation in February and March; its interaction with the Gulf Stream in April and May; its southwestward movement through the Sargasso Sea in June, July and August; and its coalescence with the Gulf Stream in September.

\section{a. Formation}

The formation of ring Bob was observed with an unusually good set of satellite infrared images. Dur-
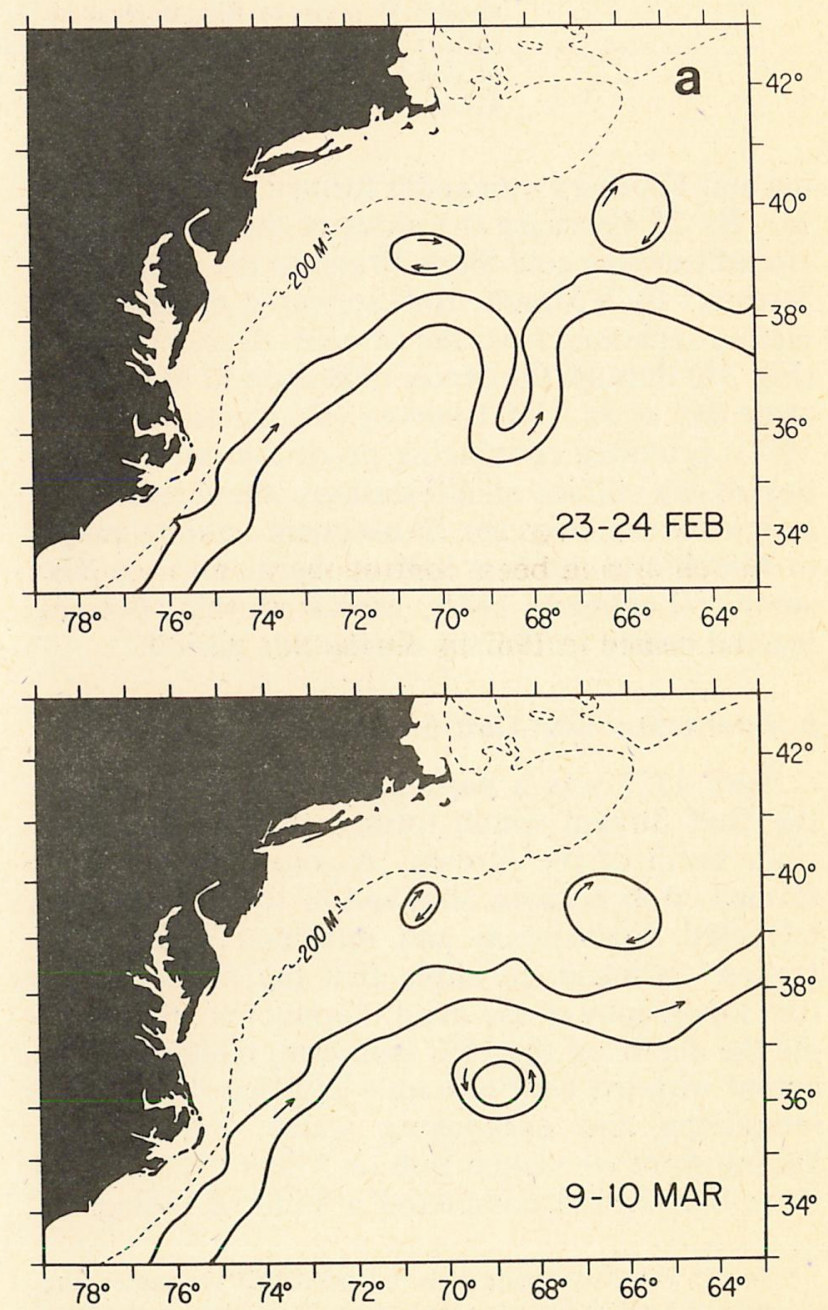


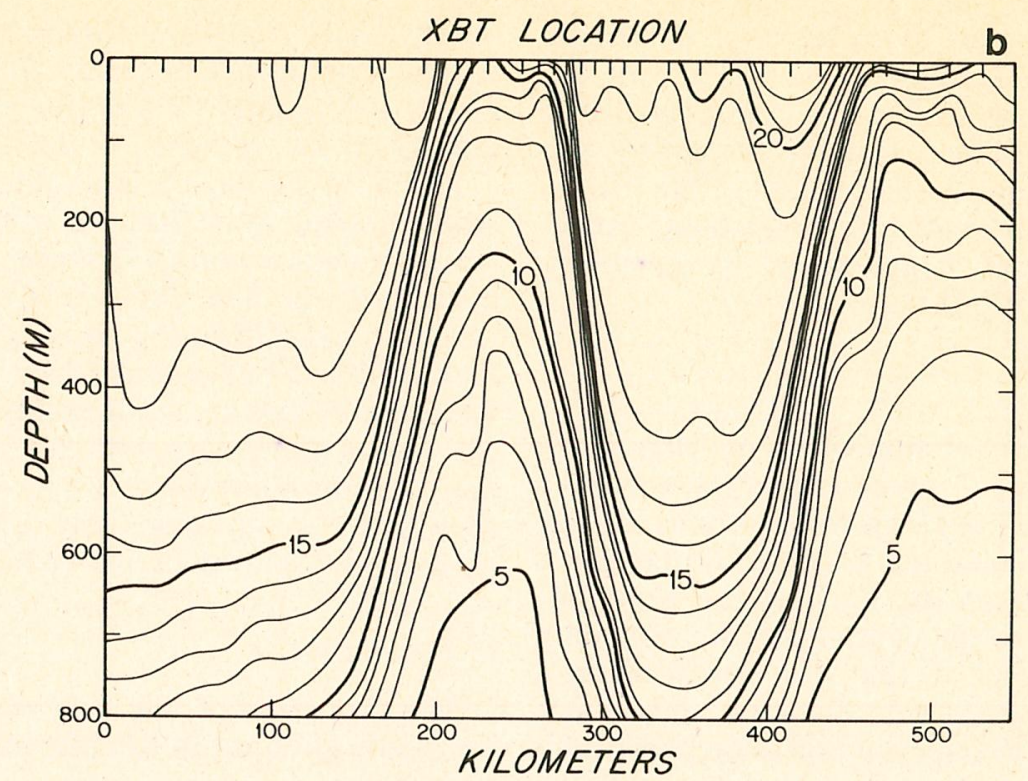

FIg. 1b. XBT section through ring Bob and the Gulf Stream on 12 March 1977 (Endeavor cruise 6). Ring Bob can be seen as a region of raised isotherms and cool surface temperatures $\left(<15^{\circ} \mathrm{C}\right)$ near the $240 \mathrm{~km}$ location; the Gulf Stream is a region of sloping isotherms and warm surface temperatures $\left(>20^{\circ} \mathrm{C}\right)$ centered near the $410 \mathrm{~km}$ location.

ing mid-February a meander formed near $69^{\circ} \mathrm{W}$ (Fig. 1a). By 25 February the sides of the meander had closed trapping cold Slope Water to the south of the Stream. ${ }^{4}$ By 9 March, Bob appeared to have completely separated from the Stream. An XBT section (Fig. 1b) through the center of Bob on 12 March, the same day as an AXBT survey (Doblar and Cheney, 1977), provided convincing proof that we had witnessed, by surface manifestations, the formation of an intense ring (Fig. 1b). Subsequent satellite images in March and the first half of April, plus an XBT survey (Leetmaa, 1977), indicated that Bob remained nearly stationary during this period.

\section{b. Interaction with Gulf Stream}

April 1977 was a particularly unstable time for the Gulf Stream which formed three anticyclonic rings north of the Stream. As one of these rings formed, Bob became attached to the Stream, was advected downstream and reformed again. "Attached" is meant to imply that the ring contours (the topography of the main thermocline, for example the depths of the $15^{\circ} \mathrm{C}$ isotherm) merge to some extent with the Gulf Stream's and that the two are interacting and exchanging water, energy, etc. During April we visited Bob on Knorr 65, launched three buoys, and completed a suite of biological,

\footnotetext{
${ }^{4}$ The 15 February image also indicated that the warm ring, located north of the Stream, advected cold water from the Shelf Water region into the left edge of the Stream; it is possible that this water was also trapped in the ring.
}

chemical and physical measurements. When our data are combined with satellite images the following complex sequence of events is revealed (Fig. 2a).

In early April Bob was located near $36.0^{\circ} \mathrm{N}$, $69.0^{\circ} \mathrm{W}$. By 14 April the Gulf Stream began to meander northward along $70^{\circ} \mathrm{W}$. By $15-17$ April Bob became connected to the Stream and began to entrain warm Gulf Stream water $\left(24^{\circ} \mathrm{C}\right)$ and advect it cyclonically around the ring center. By 28 April the northward meander had formed an anticyclonic ring near $38.5^{\circ} \mathrm{N}, 70.5^{\circ} \mathrm{W}$ and Bob had come in contact with the eastern side of the meander as it closed to form the ring. During the period 17-27 April, Bob was attached to the Stream and moved rapidly eastward with a mean speed, over 10 days, of $18 \mathrm{~cm}$ $\mathrm{s}^{-1}$ and with a peak speed of $25 \mathrm{~cm} \mathrm{~s}^{-1}$. An XBT survey at the end of April (Fig. 2b) suggested that the ring had almost completely merged with the Stream, forming a large ring/meander. Within two weeks, however, it had reformed as a separate ring. As Bob moved eastward, it collided with ring Allen which coalesced with the ring/meander Bob had become; Allen was advected rapidly downstream (75 $\mathrm{cm} \mathrm{s}^{-1}$ ) and was lost.

In mid-April we launched three satellite buoys in Bob, one near the ring center, one (731) near the high velocity region and one near the outer edge. Only one of these (731) stayed in Bob during its interaction with the Stream; the others were swept eastward in the Stream. Buoy 731, suggests that the ring center retained its cyclonic circulation through the time Bob was connected to the Stream. 

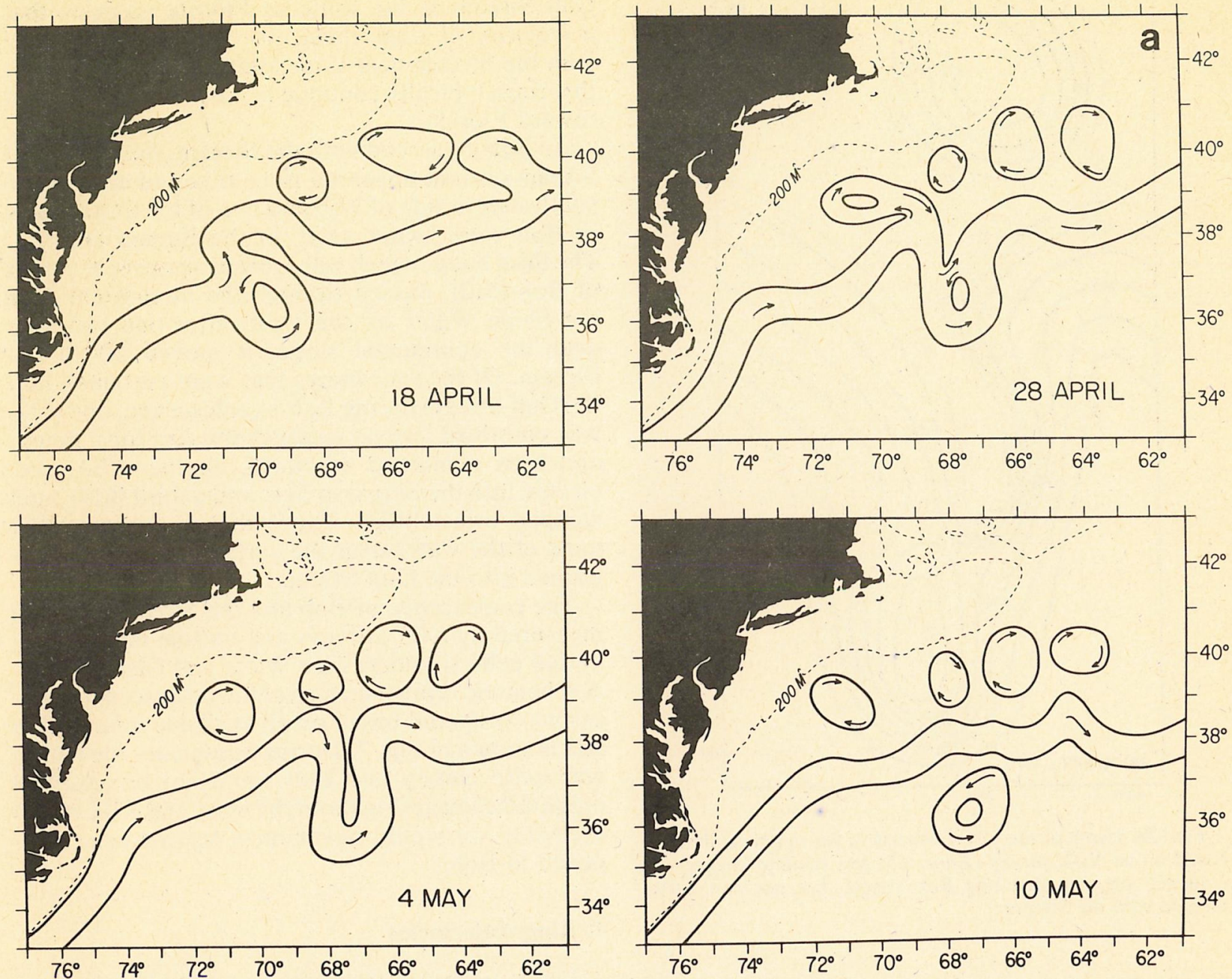

FIG. 2a. Schematic diagram of ring Bob's interaction with the Gulf Stream in April and May 1977. Bob became attached to the Gulf Stream, was advected eastward $160 \mathrm{~km}$ in 10 days, and formed again in early May. The interaction coincided with the formation of a warm core ring to the north of the Stream. Although the third panel shows an open meander, the evidence suggests that there was a closed circulation in the central region of the ring/meander.

\section{c. Southwestward movement}

The continuous movement of Bob from April to September is given by the trajectory of buoy 731 (Fig. 3). After Bob formed again in May, it began a southwestward movement through the Sargasso Sea. During Bob's southwestward translation, the buoy looped with a period varying from 1.9 days in May to 2.9 days in August, a mean radius of 40 $\mathrm{km}$ and a mean speed of $125 \mathrm{~cm} \mathrm{~s}^{-1}$ (Fig. 3b). Since the radius of the loops remained nearly constant from May to September, we conclude that the ring's rotation rate was gradually slowing, which is an indication of the ring's decay. ${ }^{5}$ A linear extrapolation

${ }^{5}$ The central part of Bob was rotating faster than the region in which buoy 731 was located. Another buoy, 512, was launched in Bob in July; it looped with a radius of $15 \mathrm{~km}$ and period of 2.4 days at the same time buoy 731 looped with a radius of 40 $\mathrm{km}$ and period of 2.9 days. of the changing angular velocity measured by buoy 731 suggests that Bob would have ceased rotating by March 1978. Bob's mean southwestward translation rate was $5.5 \mathrm{~cm} \mathrm{~s}^{-1}$; there were periods of higher speed $\left(12 \mathrm{~cm} \mathrm{~s}^{-1}\right.$ on day 179) and periods during which Bob remained nearly stationary (near $34.5^{\circ} \mathrm{N}$, $71.5^{\circ} \mathrm{W}$ from day 200 to 215 ). Endeavor cruises 8 and 11 visited Bob in May and during July-August; XBT surveys and other measurements made on these cruises indicated that Bob was nearly circular and was unconnected to the Gulf Stream at these times.

\section{d. Coalescence with the Gulf Stream}

In September Bob coalesced with the Gulf Stream and was lost. The evidence suggests that the coalescence took place rapidly and that it may have been triggered by another ring which was advected 


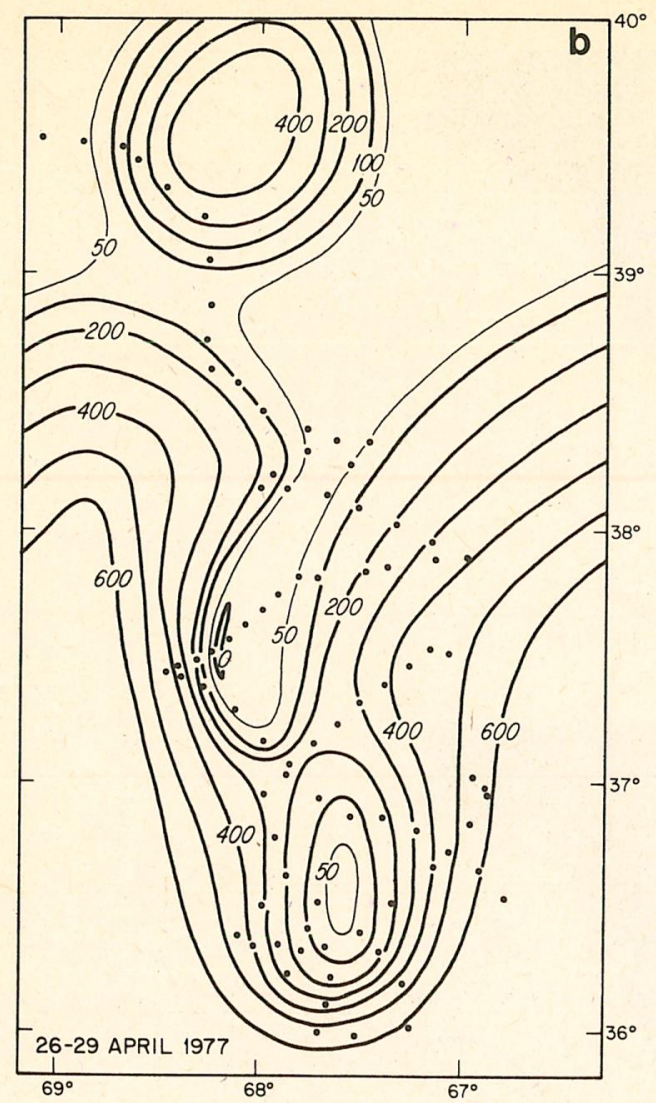

FIG. 2b. Depth of the $15^{\circ} \mathrm{C}$ isotherm in the ring/meander Bob, based on an XBT survey (Knorr 65 ) and satellite images. The evidence suggests that ring Bob almost, but not completely, merged with the Stream.

by the Stream into the vicinity of ring Bob. ${ }^{6}$ The coalescence, as observed by buoys, is summarized in Fig. 4 which shows the simultaneous trajectories of three rings, Bob, Charlie and Dave. During August, ring Dave became attached to the Gulf Stream, and was advected rapidly $\left(40 \mathrm{~cm} \mathrm{~s}^{-1}\right)$ downstream and collided with Bob which was moving westward. As Bob and Dave collided, the buoy that had been in Dave for 5 months looped once around Bob, the more intense of the two rings, and moved off in the Stream. It is interesting that as Dave was advected rapidly downstream, ring Charlie moved rapidly southward $\left(30 \mathrm{~cm} \mathrm{~s}^{-1}\right)$ as if compensating for the displacement of Dave. XBT sections through Bob, Charlie and Dave in April and July show the relative size and location of the different rings. The sections also illustrate the simultaneous presence of numerous rings in the western Sargasso Sea (Fig. 5). The frequent occurrence of rings just off shore of the

\footnotetext{
${ }^{6}$ Note that Allen also coalesced as a ring (Bob) was moving downstream attached to the Gulf Stream.
}

Gulf Stream as far south as Florida suggests that a majority of rings must not coalesce completely with the Stream near Cape Hatteras as Bob did but that rings typically continue to move southwestward toward Florida.

As Bob coalesced with the Stream, the main Gulf Stream current appeared to be diverted around the southeastern side of Bob and two of the three buoys in Bob were swept away in the Stream (Fig. 6). The third buoy, which was located nearest the center of Bob (512), passed through the Stream and into the Slope Water on the west; after one last loop near the continental slope, it moved off in the Stream. Of the four buoys that were entrained into the Gulf Stream during Bob's coalescence, one (512) was entrained into an anticyclonic ring for a month and then continued eastward, another (731) was ejected into the Sargasso Sea, and a third (614) soon stopped transmitting. The evidence suggests that most of the water near the surface of Bob was entrained into the Gulf Stream.

The coalescence of Bob and the Stream was also measured by XBT surveys and bottom mounted inverted echo sounders (see Watts and Olson, 1978). A schematic representation of the coalescence process was prepared based on all available information and is shown in Fig. 7. During September the region was quite cloudy and Bob could not be resolved on satellite images; without the buoy and XBT measurements we would never have known what happened to Bob.

\section{Ring trajectories}

Buoys were launched into several different rings in order to measure their movement. When launched near the center of a cyclonic ring, buoys showed a tendency to move outward toward the high-velocity part of the ring and to stay there, circling the ring center. One buoy stayed in a ring 8 months and made 86 loops. The general pattern we observed is that rings frequently interact with the Gulf Stream and as this occurs buoys are sometimes swept away in the Stream. When one ring encountered the Blake Plateau, its buoy stopped looping suggesting that the topography interfered with the usual ring circulation. Three buoys which were located in anticyclonic rings north of the Stream all came out of the rings and into the Stream rather quickly, typically in one month.

The ring trajectories suggest two distinctive types of movement (Fig. 8, Table 1). The first is a general westward, sometimes northwest, sometimes southwest, movement of rings that were not touching the Gulf Stream (rings 2, 3, 4, 5, 6, 7, 8, 9, 10, 14 and $15)$. The characteristic speed of the westward movement was $5 \mathrm{~cm} \mathrm{~s}^{-1}$ (rings 4, 5, 6 and 7) although 


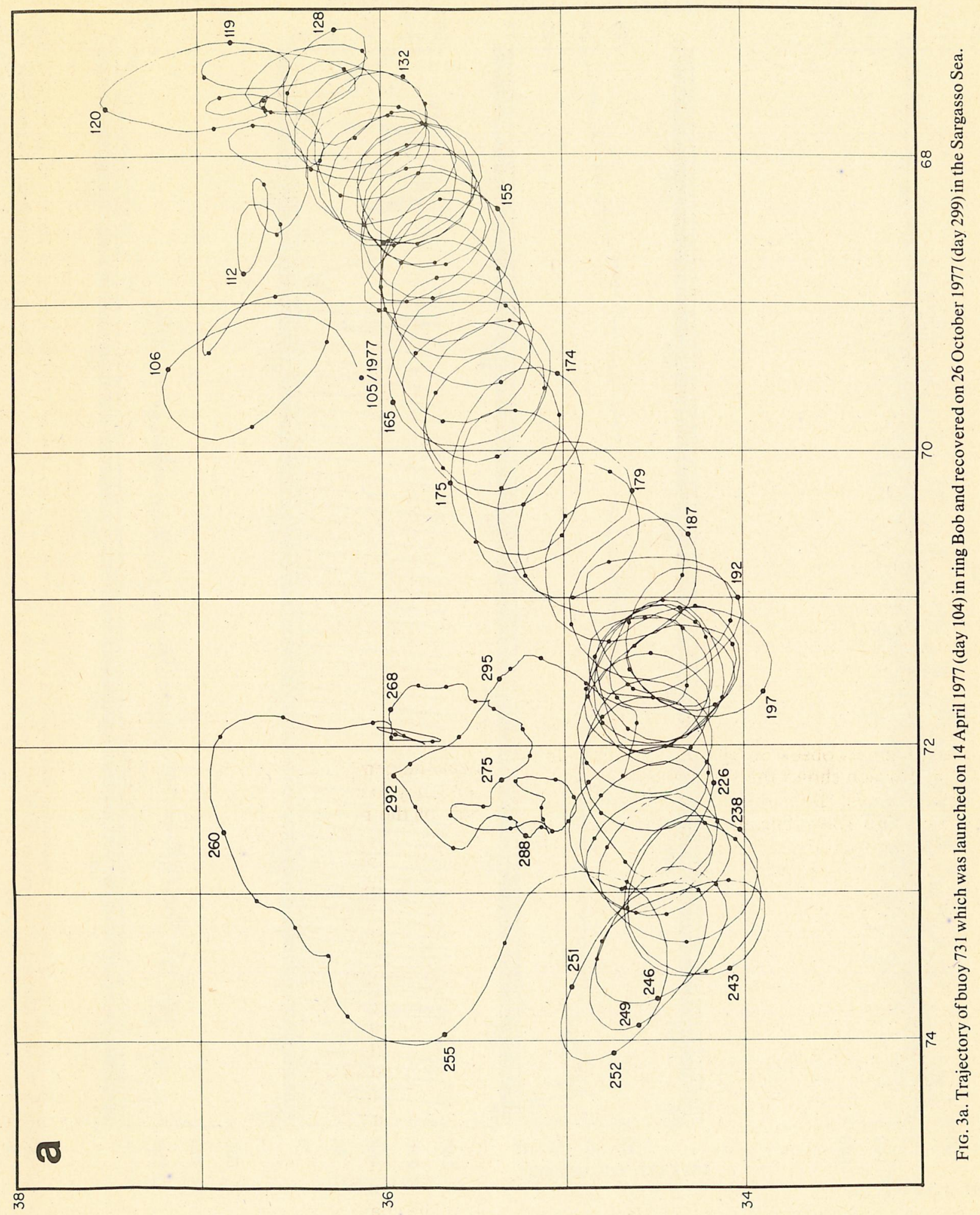



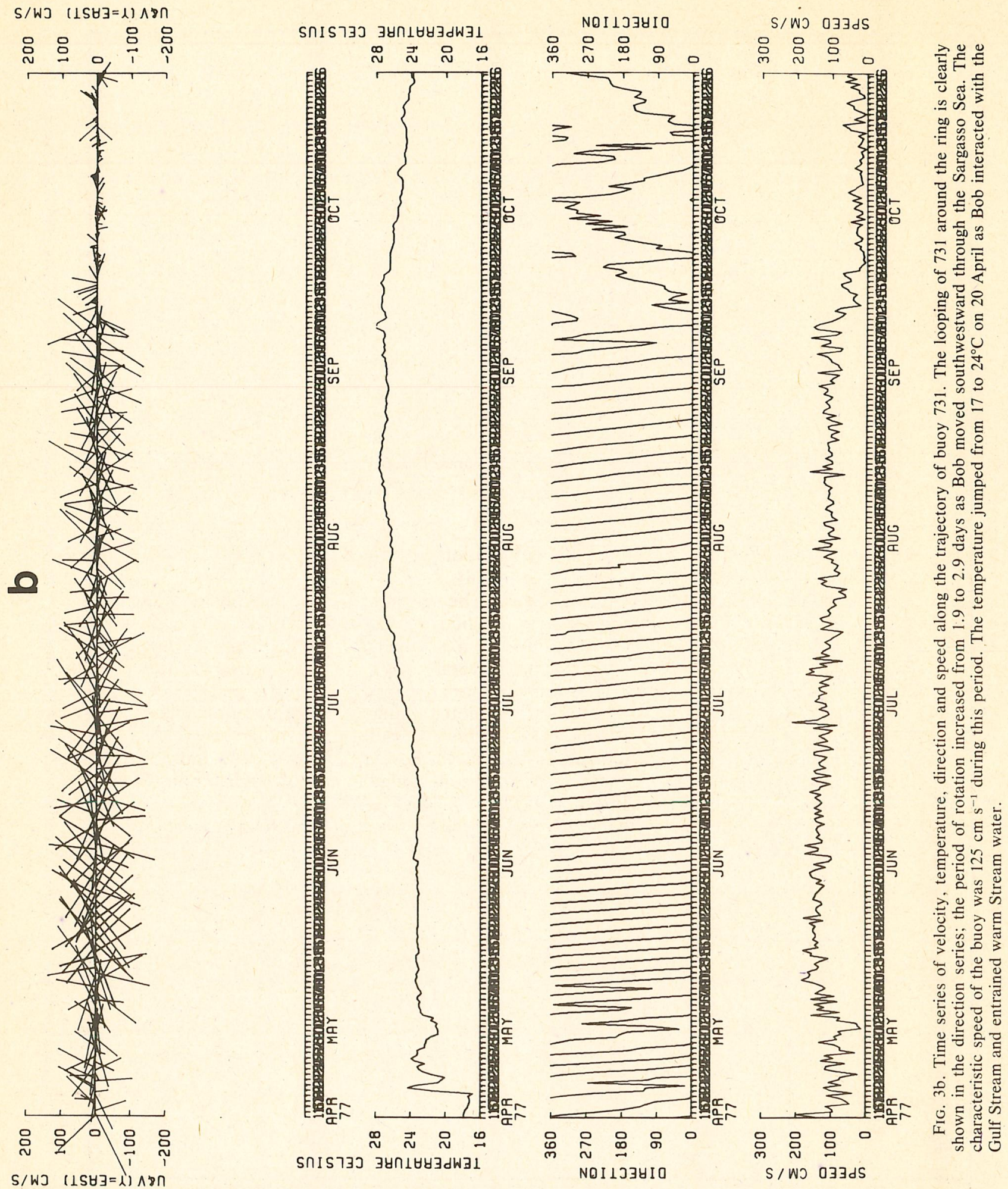


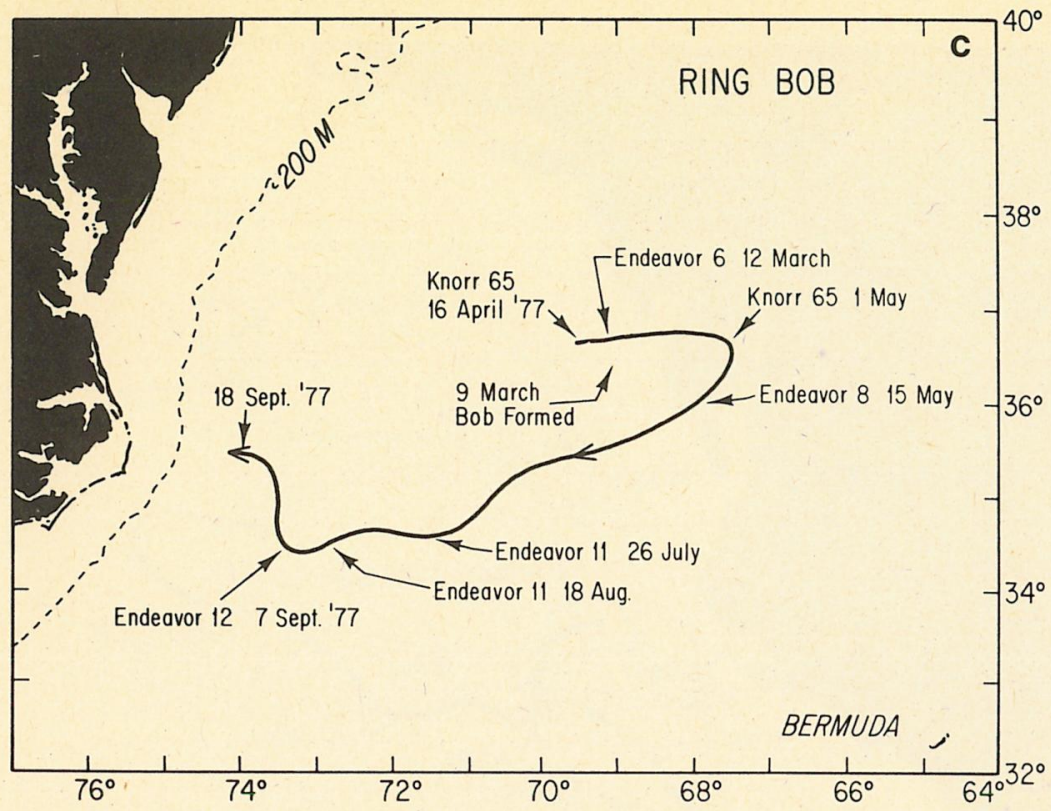

FIG. 3c. Schematic summary of ring Bob's movement from free-drifting. buoys, XBT surveys and infrared images.

there are significant variations around this value. ${ }^{7}$ The second type of movement is directed parallel to the Gulf Stream and in a downstream direction; it occurs when a ring is attached to and interacting with the Gulf Stream (rings 1, 7, 8, 9, 11 and probably 2 and 3 ). The interactions are ended either by the ring splitting off from the Stream again (rings $3,7,8$ and 9), sometimes strongly modified, or by the ring coalescing totally with the Stream (rings $1,7,8$ and 9). During the interactions of rings $1,7,8$ and 11 with the Stream the buoy's rotation rate increased and the radius decreased; these rings were apparently "spun up" during the interaction (Richardson et al., 1979a). The downstream movement of rings that were attached to the Stream was at times very fast, $25 \mathrm{~cm} \mathrm{~s}^{-1}$ for ring 7 (Bob), 40 $\mathrm{cm} \mathrm{s}^{-1}$ for ring 1 , and $75 \mathrm{~cm} \mathrm{~s}^{-1}$ for ring 8 .

A result of repeated ring-Gulf Stream interactions is that rings frequently moved in large, clockwise loops which have a characteristic diameter of 170 $\mathrm{km}$, period of 2.5 months and speed of $8 \mathrm{~cm} \mathrm{~s}^{-1}$. The loops consisted of an eastward movement when the ring was attached to the Stream, a southward movement as the ring broke away from the Stream, a westward movement when the ring was free from the Stream, and a northward movement as the ring

\footnotetext{
${ }^{7}$ A general westward, then southwestward, movement of rings was described by Lai and Richardson (1977) from intermittent observations of numerous rings. The present study suggests that the movement of rings is not as simple as that presented by Lai and Richardson and that they may have included different rings in what they concluded were individual trajectories.
}

began another interaction (rings 3,8 and 9). A similar motion was found by Fuglister (1977) in his 1967 study.

The region near the New England Seamounts is a particularly complicated one. There was evidence for a semipermanent ring/meander in this region. Several buoys moving eastward in the Stream became entrained for various periods of time in this structure (ring 11), and those rings that were found in this region did not last long before they coalesced with the stream (rings 11, 12 and 13). Thus evidence is added to that of Fuglister and Worthington (1951) and Fuglister (1963) that the region near the seamounts is one in which large meanders and rings are produced.

The ultimate fate of rings is coalescence with the Gulf Stream. Although there is the possibility that rings can move southward into the southern Sargasso Sea and slowly decay there separate from the Stream, no evidence for this possibility comes from the rings tracked by buoys. No rings have been identified south of $30^{\circ} \mathrm{N}$ except in the extreme western region. There was a hint from temperature anomaly studies that rings can penetrate southward near the Bahama Islands to as far south as $25^{\circ} \mathrm{N}$ (Barrett, 1971; Parker, 1971; Lai and Richardson, 1977); however, the anomalies were quite weak and the observations are tentative at best.

\section{Ring-Gulf Stream interactions}

We have observed three different modes of behavior in rings which interact with the Gulf Stream. 


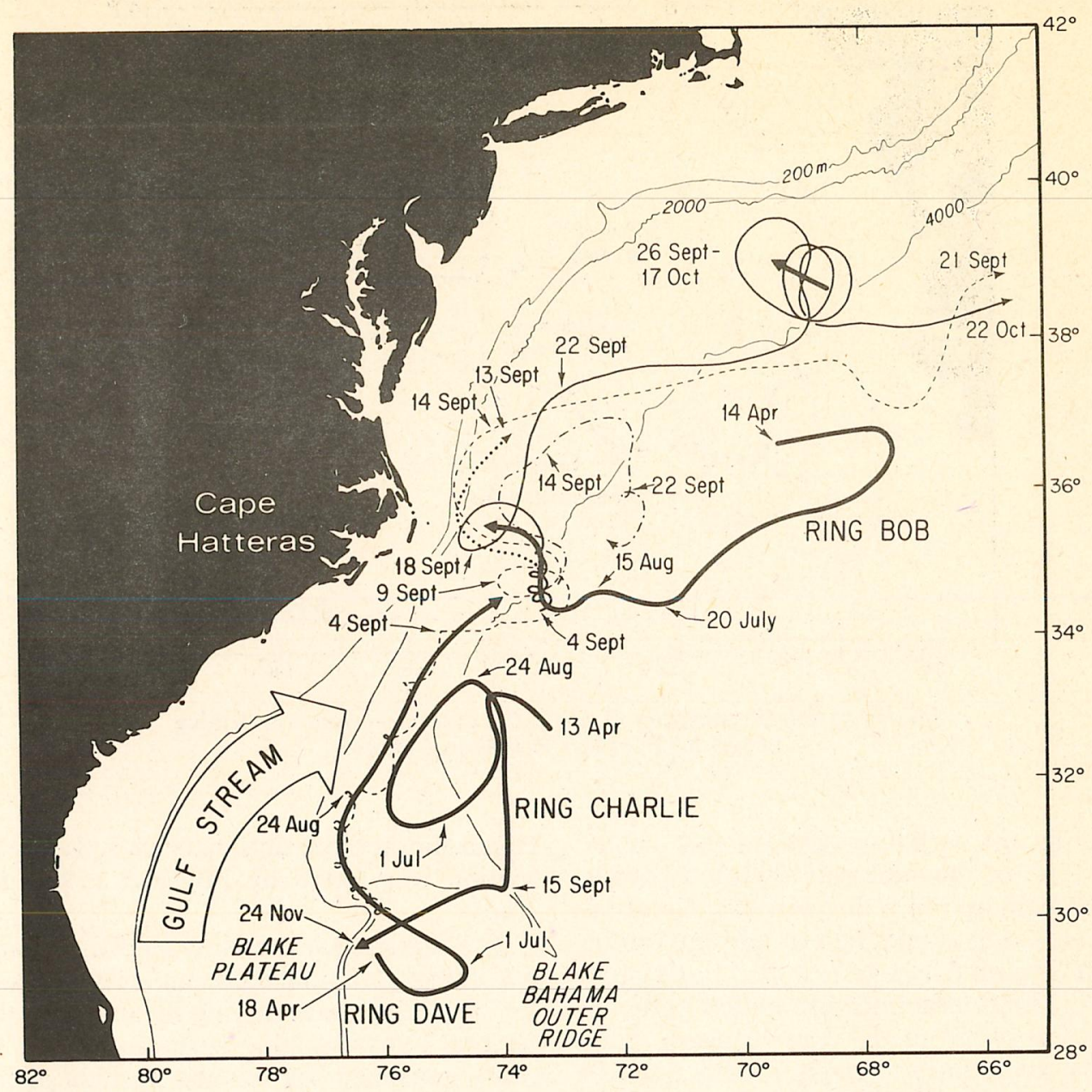

FIg. 4. Simultaneous trajectories of three rings, Bob, Charlie and Dave (dark lines) from April to November 1977 and portions of four buoy trajectories (lighter lines). Ring Dave became attached to the Gulf Stream in August and was advected northeastward in the Stream. In September, Dave collided with Bob; the buoy that had been in Dave made one loop around Bob and then moved downstream in the Stream. As Bob coalesced with the Stream all three buoys were entrained into the Stream and were swept away.

Conceptual models of these modes are shown schematically in Fig. 9. In model 1 (Fig. 9a), when a relatively intense ring becomes attached to the Stream, the main Gulf Stream current is diverted and flows around the ring. In the final stage the ring merges completely with the Stream which is in the form of an open meander. It is possible for the meander to now form another ring or to dissipate. Model 1 resembles the formation of a ring with the exception that the steps of the process are reversed. During the coalescense, it is possible to have water from the ring center transported across the Stream into the Slope Water region. We have observed this mode of coalescence on at least four occasions including ring Bob (rings $7,9,13$, and the northern ring in Cheney et al., 1976).

Model 2 shows an example of a relatively weak ring which becomes attached to the Gulf Stream, is advected downstream and is presumably lost (Fig. $9 b)$. On two occasions we have observed buoys in a ring to continue looping as they were accelerated eastward in the Stream (rings 1 and 8). Although it seems possible that these rings could form again, we have no evidence from the buoy data that they do. We therefore tentatively conclude that these rings merged completely with the Stream.

On two occasions (rings 7 and 8) the final coalescence of a ring and the Stream may have been triggered by another ring which was advected downstream and collided with the ring subsequently lost. Thus there is evidence of ring-ring-Gulf Stream interaction.

Model 3 shows an example of a ring which becomes attached to the Gulf Stream, moves down- 

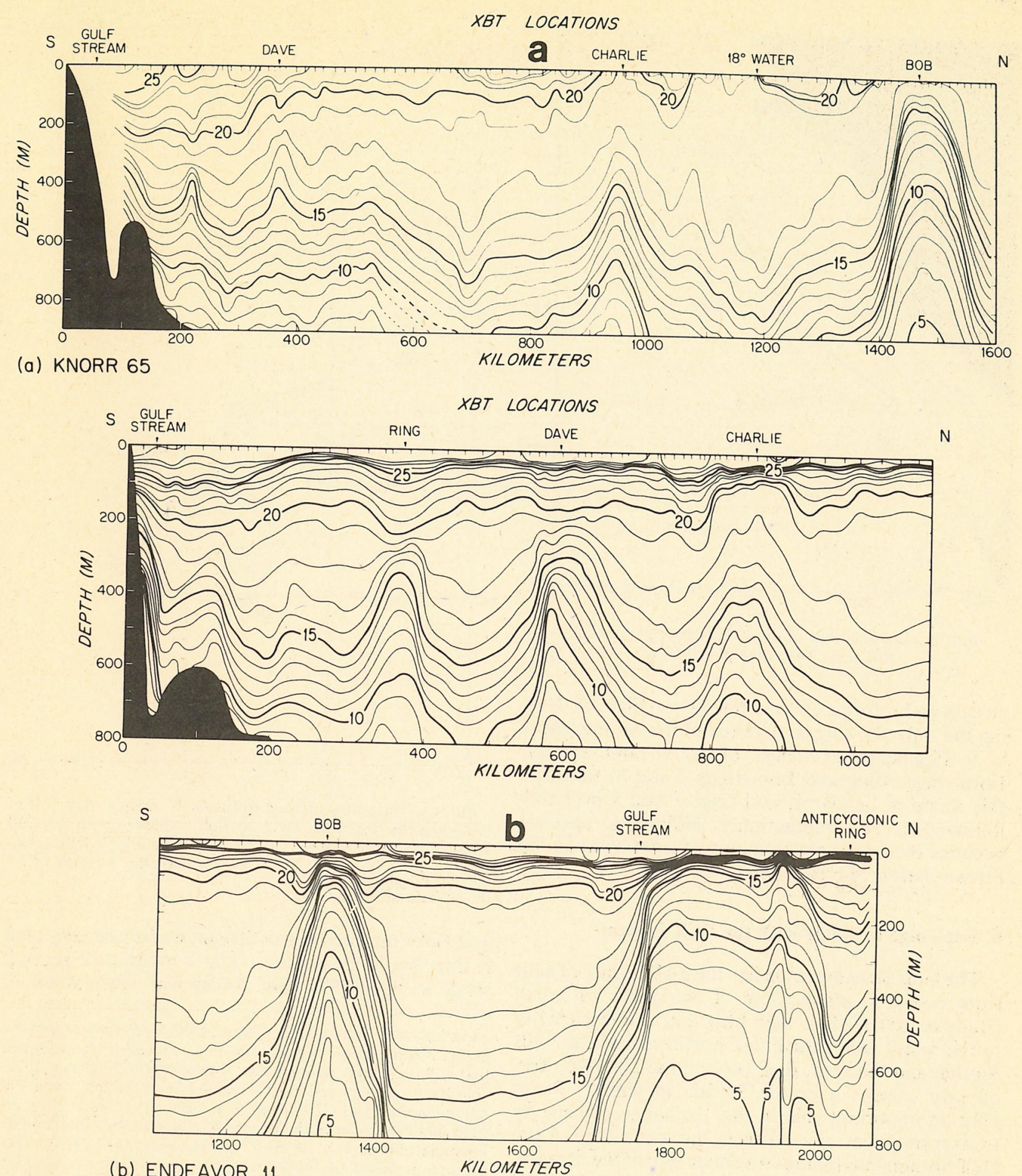

(b) ENDEAVOR 11

KILOMETERS

FIg. 5 (a) Temperature section through the Sargasso Sea, offshore of the Gulf Stream from Florida toward $38^{\circ} \mathrm{N}, 68^{\circ} \mathrm{W}$ (Knorr 65, 9-14 April 1977). The section passed through the centers of at least three rings, Bob, Charlie and Dave (as measured by short Gulf Stream water which can be seen over Bob's water, located near $1200 \mathrm{~km}$. Ring Bob was in the process of entraining warm the temperature measurements of buoy 731 . Wh southwestern flank. The entrainment was also seen with satellite images and in with the Gulf Stream.

(b) Temperature secti

(Endeavor 11, 26 July-18 August 1977). The centers of rings Bob Charliclonic rings, the Gulf Stream and an anticyclonic ring 


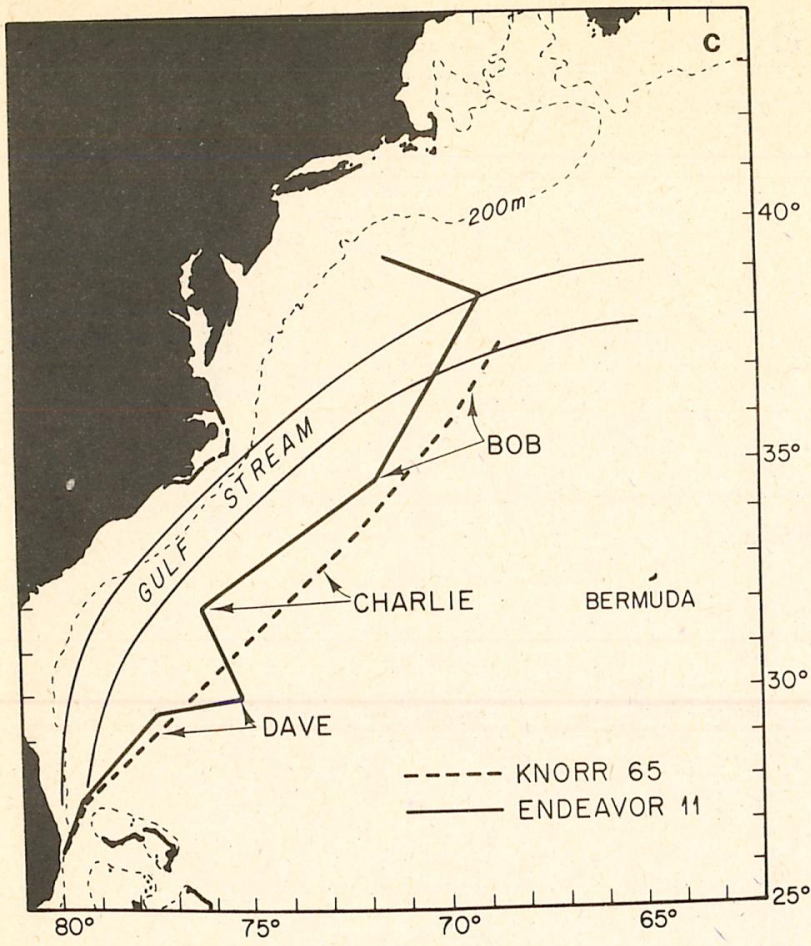

FIG. 5c. The locations of the XBT temperature sections and rings Bob, Charlie and Dave.

stream and reforms as a modified ring (Fig. 9c). During the time the ring is attached to the Stream there is a significant exchange of water and energy. Both rings Allen and Bob (rings 7 and 8) followed this mode of behavior, and rings 3 and 9 probably followed it. The interaction is difficult to observe because the buoys are frequently swept away in the Stream before the ring can form again.

\section{Exchange of water with the Gulf Stream}

The Gulf Stream region has the highest flux of heat from ocean to atmosphere of any place on earth (Budyko, 1963). This high heat flux is due partially to the warm water advected northward in the Gulf Stream and the cold, dry, continental air which frequently sweeps over the Stream in winter. Rings play an important role in this exchange of heat by transporting warm water from the warm core of the Gulf Stream into regions on either side of the Stream. The transport occurs whenever a ring forms and also whenever a ring interacts with the Stream and exchanges water with it. ${ }^{8}$ For example, both Allen

\footnotetext{
${ }^{8}$ An estimate of the exchange of water in the upper $150 \mathrm{~m}$ between the Gulf Stream and rings due to their formation, interaction and coalescence with the Stream is $6 \times 10^{6} \mathrm{~m}^{3} \mathrm{~s}^{-1}$; this value amounts to $40 \%$ of the transport in the Gulf Stream itself for this layer which has been measured to be $15 \times 10^{6} \mathrm{~m}^{3} \mathrm{~s}^{-1}$ (Richardson et al., 1969). During their formation, rings transport
}

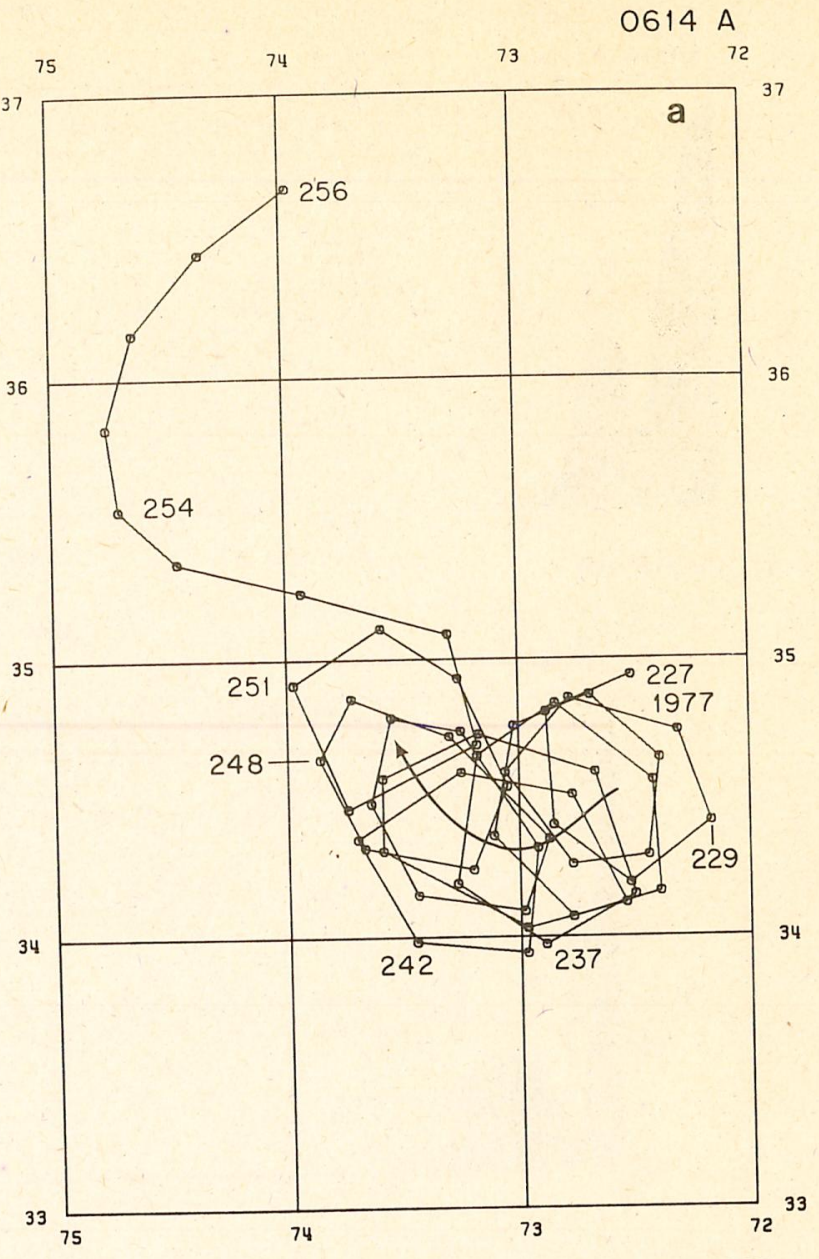

FIG. 6a. Trajectory of buoy 614 from 15 August (day 227) to 13 September (day 256), 1977, as Bob coalesced with the Gulf Stream. Two positions per day are shown by circles; labels indicate the day of the year. The looping motion has a period of 2.9 days and a radius of $40 \mathrm{~km}$.

and Bob entrained warm Stream water and advected it into the Sargasso Sea. The temperature section made in April 1977 (Fig. 5a) shows warm water in

an estimated $2 \times 10^{6} \mathrm{~m}^{3} \mathrm{~s}^{-1}$ of warm Gulf Stream water into the areas adjacent to the Stream. For this estimate it was assumed that 5-8 rings form on each side of the Stream (Fuglister, 1972) and that each ring consists of a region of Gulf Stream water 200 and that each ring cons $150 \mathrm{~m}$ deep. The exchange of water between $\mathrm{km}$ in diameter and $150 \mathrm{~m}$ deep. The exchange of water between is estimated to be $4 \times 10^{6} \mathrm{~m}^{3} \mathrm{~s}^{-1}$ (Richardson et al., 1979a). This is estimated to be $4 \times 10^{6} \mathrm{~m}^{3} \mathrm{~s}^{-1}$ (Richardson the on the average, six rings are found next to the Stream and that each of these rings interacts with the Stream every two months. The heat flux induced by rings was estimated by coupling the rates of exchange of water with the temperature difference between the warm core of the Gulf Stream and the cooler water found on both sides of the Stream; it amounts to about $36 \times 10^{19} \mathrm{cal}^{\text {year }}{ }^{-1}\left(5 \times 10^{13} \mathrm{~W}\right)$. Stream; it amounts calculated using an average temperature difference of $2^{\circ} \mathrm{C}$, a compromise between the small difference observed in summer and the larger one in winter. In late winter the temperature difference between the Slope Water and the Stream reaches $12^{\circ} \mathrm{C}$, and between the Sargasso Sea and the Stream, $6^{\circ} \mathrm{C}$. 


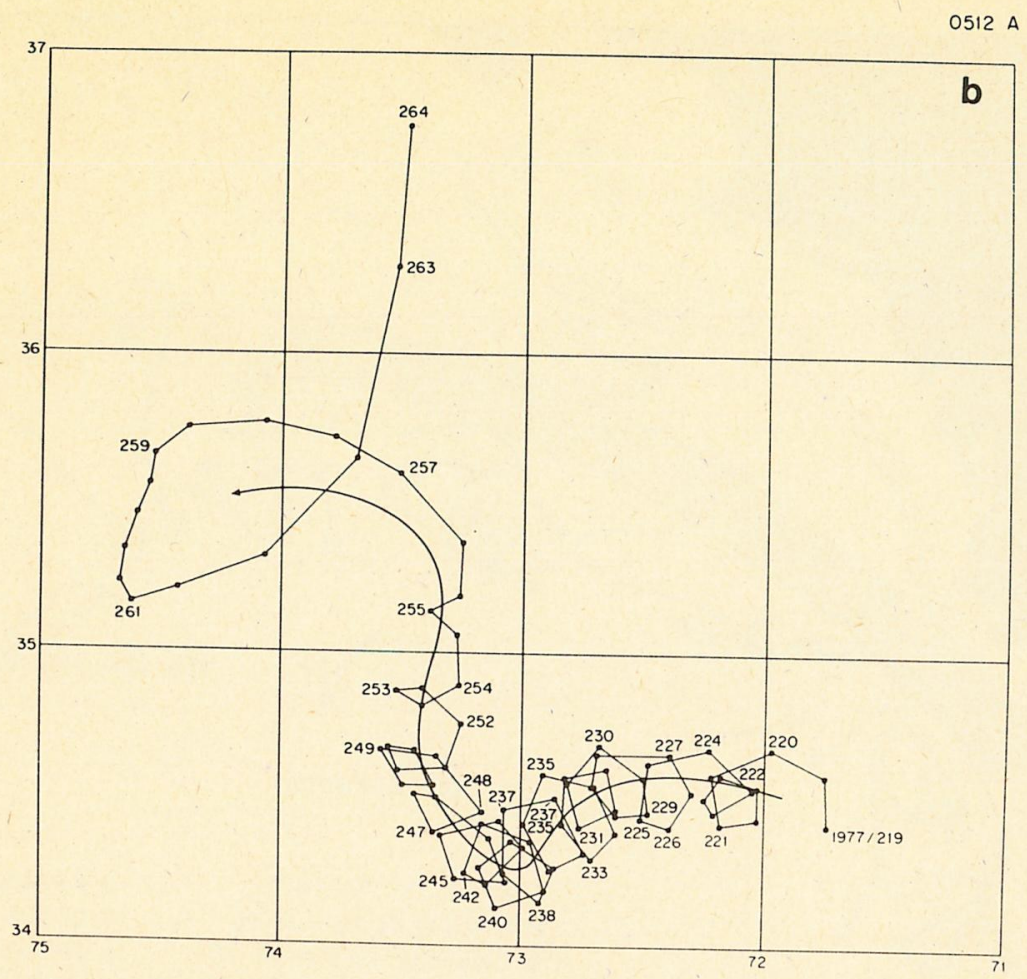

FIg. 6b. Trajectory of buoy 512 from 7 August (day 219) to 21 September (day 264), 1977, as Bob coalesced with the Gulf Stream. The loops have a period of 2.4 days and a radius of $15 \mathrm{~km}$.

the process of being entrained into Bob and also warm water over both flanks of Charlie. The warm water in Charlie is interpreted to be the remnant of an interaction with the Stream; it is clearly seen on an excellent series of infrared images that exist for April. These images, like others of different rings, show that the warm surface water in rings, originally Gulf Stream water, is mixed into areas surrounding the rings and sometimes exchanged from ring to ring. Because of the rapid rotation and translation of rings, the warm Gulf Stream water is spread throughout wide areas of the Slope Water and Sargasso Sea in a period of weeks. Of course some of this water is reentrained back into the Gulf Stream again during the interactions and final coalescences of rings.

On occasion during winter, the surface water in the Sargasso Sea is cooled to $18^{\circ} \mathrm{C}$ and deep layers of vertically mixed water are formed (Worthington, 1959). The horizontal transport of warm water by rings may be important in limiting the area in which $18^{\circ} \mathrm{C}$ water can form and the amount of it that does form. The winter of 1976-77 was a particularly cold one and one in which newly formed $18^{\circ} \mathrm{C}$ water was observed (Leetmaa, 1977; Worthington, 1977). The new $18^{\circ} \mathrm{C}$ water was also measured on Knorr 65 ; it can be seen in Fig. $5 \mathrm{a}$ and coincides with the deep spot in the thermocline where the $15^{\circ} \mathrm{C}$ iso-
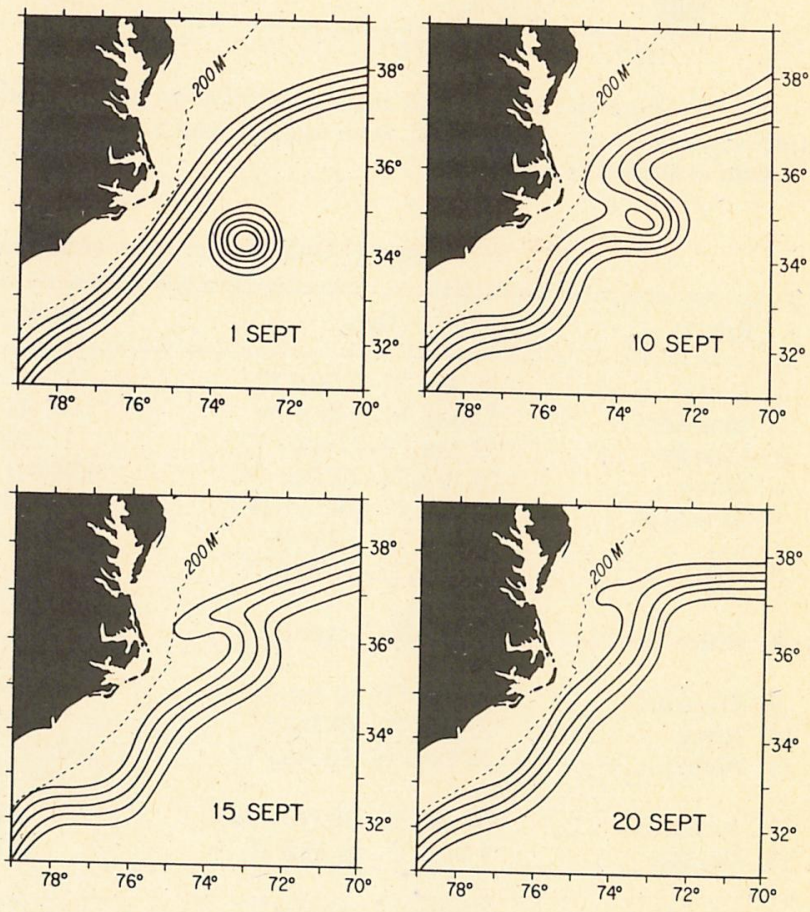

FIG. 7. Schematic diagram showing the coalescence of ring Bob with the Gulf Stream in September, 1977 (after Watts and Olson, 1978). Contours in the ring and Gulf Stream indicate variations in depth of the main thermocline; they are inferred from XBT surveys, buoy trajectories and infrared images. 


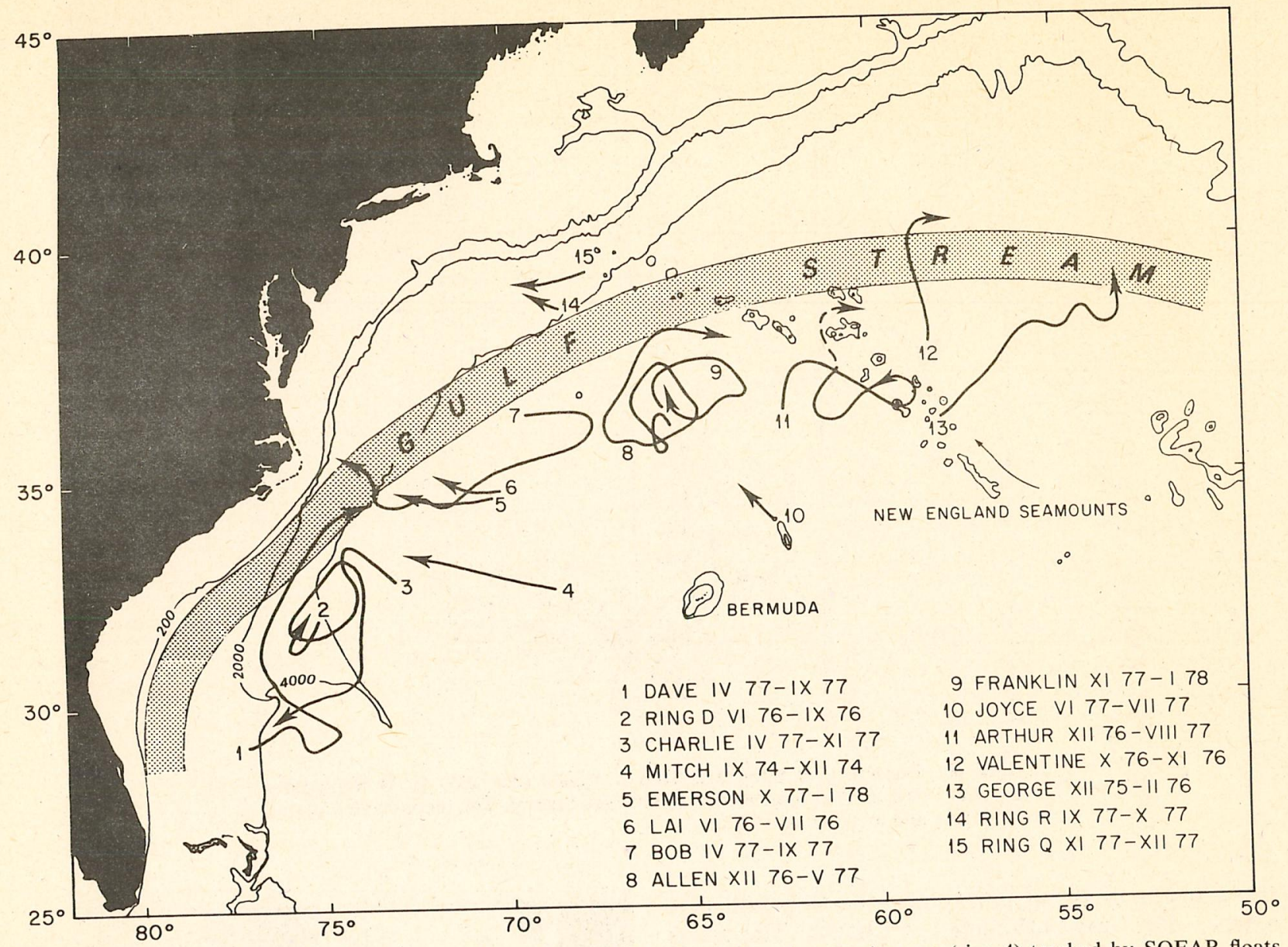

FIG. 8. The trajectories of all rings continuously tracked with free-drifting buoys plus one (ring 4) tracked by SOFAR floats (1976). The dates during which each ring was followed are given in Table 1. The math of the Gulf Stream is shown by shading.

TABLE 1. Gulf Stream rings continuously tracked with free-drifting buoys.

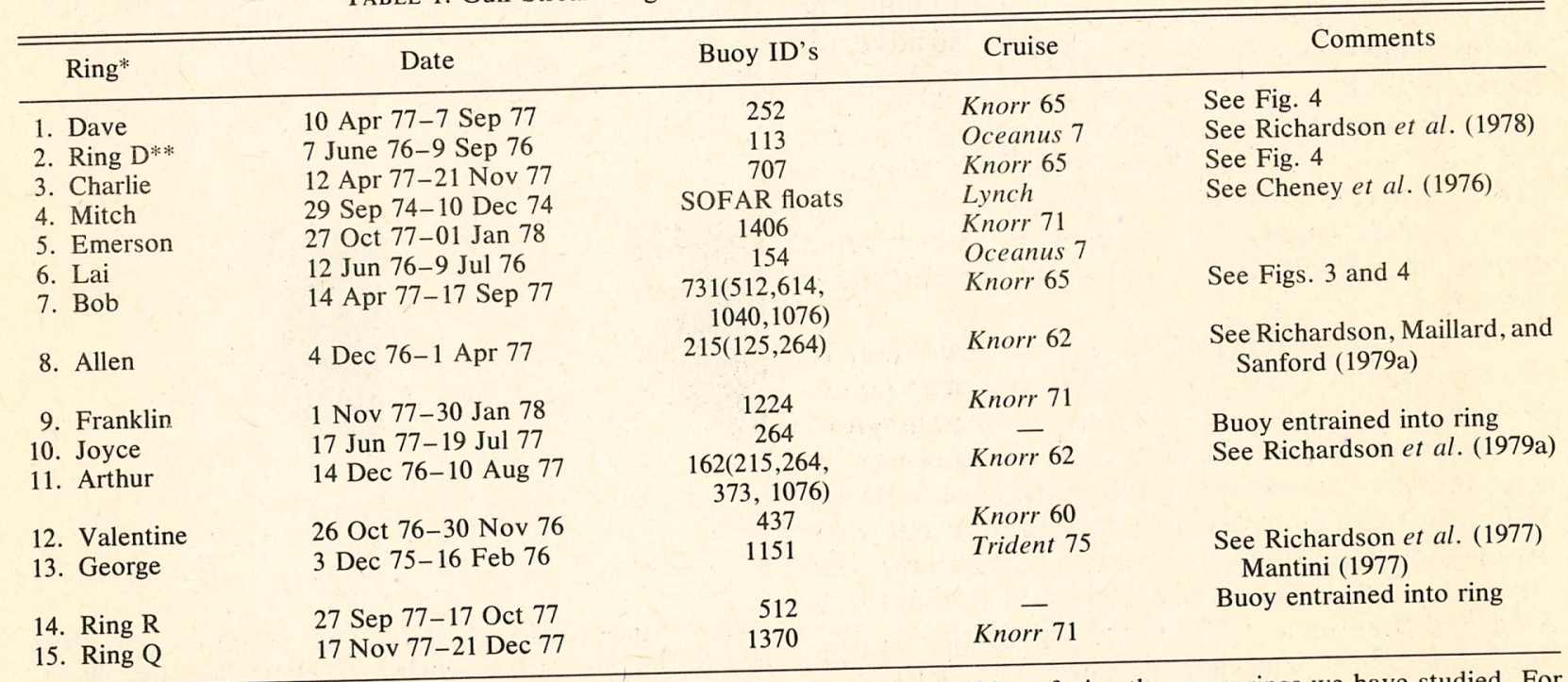

* Rings are indicated by their numbers in Fig. 8; the names are used to avoid confusing the many rings we have studied. For detailed buoy trajectories and velocities see Richardson et al. (1979b).

** Ring D was also tracked by SOFAR floats from mid-May to mid-October 1975 (Cheney, 1977); during this time Ring D followed very closely the southwestward trajectory of ring Bob. 

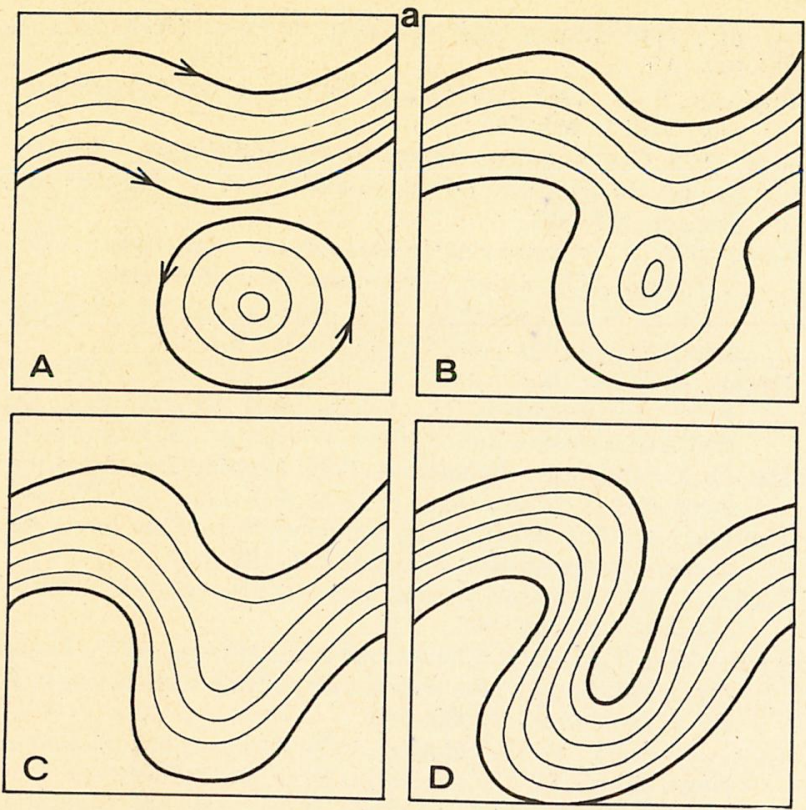

FIG. 9a. Conceptual model of the total coalescence of a ring and the Gulf Stream, during which an open meander is formed. Contours in this figure represent the topography of the thermocline. As the ring impinges on the Stream, the Stream is diverted around the ring.

therm reached a depth of $845 \mathrm{~m} .{ }^{9}$ A satellite image on 12 April 1977, the same day as our observation of the $18^{\circ} \mathrm{C}$ water, indicated the existence of a cool region $\sim 200 \mathrm{~km}$ in diameter over the $18^{\circ} \mathrm{C}$ water. This cool region is interpreted to be the surface outcropping of the $18^{\circ} \mathrm{C}$ water; it was bounded by warmer water, a significant portion of which was located in rings Bob and Charlie. Thus there is evidence that $18^{\circ} \mathrm{C}$ water may form in relatively small areas, the size and location of which are influenced by rings. Presumably the $18^{\circ} \mathrm{C}$ water is also advected and redistributed by the circulation of nearby rings, much as surface water is.

\section{Summary}

Satellite-tracked free-drifting buoys were used to follow the movement of Gulf Stream rings and to measure their interactions with the Gulf Stream. The movement of rings was generally westward when they were away from the Stream, and in the same direction as the Stream when they were attached to the Stream. The usual fate of rings was to coalesce with the Gulf Stream; during coalescence the rings either turned into open meanders or were advected downstream. At times rings interacted with the Gulf

${ }^{9}$ Leetmaa (1977) and Worthington (1977) describe measurements made during March and April, 1977 on the Researcher. On Knorr 65 we had a rendezvous with the Researcher in the area of newly formed $18^{\circ} \mathrm{C}$ water and thus our measurements (Fig. 5a) coincide with theirs in this region.
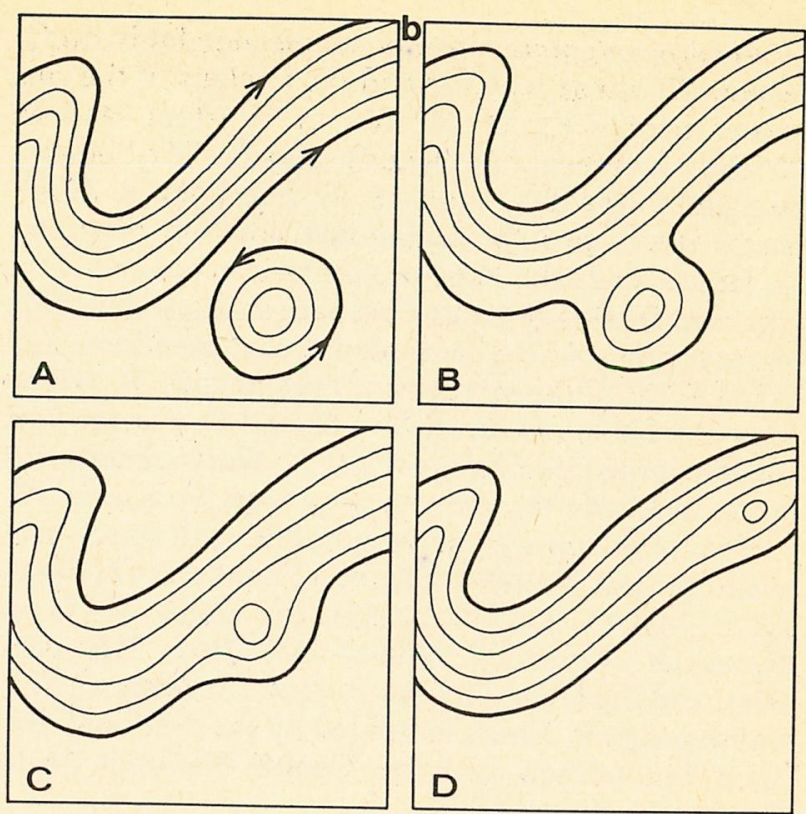

FIG. 9b. Conceptual model of the coalescence of a ring and the Gulf Stream during which the ring is accelerated and advected downstream.

Stream, exchanged water and energy, and reformed as modified rings. The most significant findings of this study are about the complicated life histories of rings and the energetic interactions with the Stream. Our original concept of a ring slowly decaying in the Sargasso Sea has become untenable.
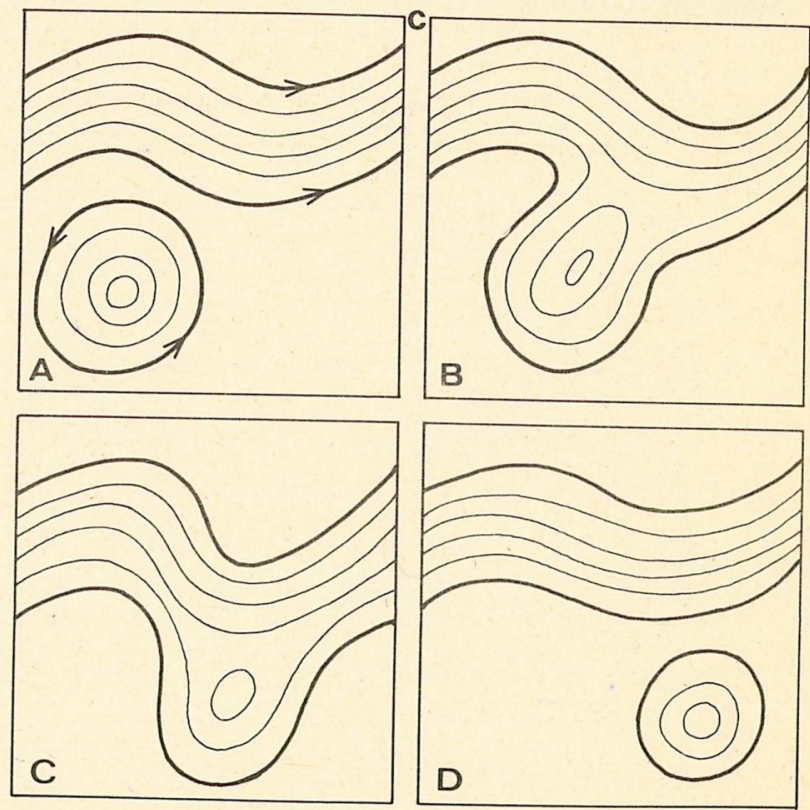

FIG. 9c. Conceptual model of the interaction or partial coalescence of a ring and the Gulf Stream during which a ring exchanges water and energy with the Stream, is advected downstream but then forms again as a ring. 
Acknowledgments. Many people aided this study, especially those who formed the nucleus of the ring experiment, i.e., D. Kester, A. Vastano and P. Wiebe. J. Wheat, G. Knapp and S. Waskilewicz assisted in the data analysis, G. Flierl and R. Goldsmith developed the spline-interpolation program, $\mathrm{S}$. Honjo made the XBT section on Endeavor 6 (Fig. $1 \mathrm{~b})$, and D. Haight helped prepare and assemble this manuscript. NASA provided buoy positions and NOAA NESS the satellite infrared images. P. Wiebe was chief scientist on Knorr 65 and D. Kester was chief scientist on Endeavor 11. R. Watts generously made available the observations from Endeavor 12.

This research was made possible with funds provided by the National Science Foundation (Grants OCE75-08765, OCE76-82059), the Office of Naval Research (Contract N00014-74-C-0262, NR 083004), and the United States-France Exchange of Scientist program which is funded by the National Science Foundation and the Centre National de la Recherche Scientifique.

\section{REFERENCES}

Barrett, J. R., 1971: Available potential energy of Gulf Stream rings. Deep-Sea Res., 18, 1221-1231.

Budyko, M. I., 1963: Atlas of Heat Balance of the Earth. Academy of Sciences, Moscow, $69 \mathrm{pp}$

Cheney, R. E., 1977: Entrapment of SOFAR floats by Gulf Stream rings. POLYMODE News No. 31 (unpublished manuscript).

W. W. Gemmill, M. K. Shank, P. L. Richardson and D. Webb, 1976: Tracking a Gulf Stream ring with SOFAR floats. J. Phys. Oceanogr., 6, 741-749.

Doblar, R. A., and R. E. Cheney, 1977: Observed formation of a Gulf Stream cold core ring. J. Phys. Oceanogr., 7, 944-946.

Fuglister, F. C., 1963: Gulf Stream '60. Progress in Oceanography, Vol. 1, 265-383.

1972: Cyclonic rings formed by the Gulf Stream, 1965-66. Studies in Physical Oceanography, Vol. 1, Gordon and Breach, 137-167.

1977: A cyclonic ring formed by the Gulf Stream 1967. A Voyage of Discovery, Pergamon Press, 177-198.

A and L. V. Worthington, 1951: Some results of a multiple ship survey of the Gulf Stream. Tellus, 3, 1-14.

Hagan, D. E., D. B. Olson, J. E. Schmitz and A. C. Vastano, 1978: A comparison of cyclonic ring structures in the northern Sargasso Sea. J. Phys. Oceanogr., 8, 6136-6144.

Li D. Y., and P. L. Richardson, 1977: Distribution and movement of Gulf Stream rings. J. Phys. Oceanogr., 7, 670-683.

Leetmaa, A., 1977: Effects of the winter of 1976-77 on the northwestern Sargasso Sea. Science, 198, 188-189.

Parker, C. E., 1971: Gulf Stream rings in the Sargasso Sea. DeepSea Res., 18, 981-993.

Richardson, P. L., R. E. Cheney and L. A. Mantini, 1977. Tracking a Gulf Stream ring with a free drifting surface buoy. $J$. Phys. Oceanogr., 7, 580-590.

and L. V. Worthington, 1978: A census of Gulf Stream rings, Spring 1975. J. Geophys. Res., 83, 6136-6144. C. Maillard and T. Sanford, 1979a: The life history of cyclonic Gulf Stream ring Allen. J. Geophys. Res. (in press). , J. J. Wheat and D. Bennett, 1979b: Free-drifting, satellitetracked buoy trajectories in the Gulf Stream system 19751978. Woods Hole Oceanogr. Inst., Tech. Rep. 79-4, January, $159 \mathrm{pp}$.

Richardson, W. S., W. J. Schmitz, Jr., and P. P. Niiler, 1969: The velocity structure of the Florida current from the Straits of Florida to Cape Fear. Deep-Sea Res., 16(Suppl.), 225-231.

Watts, D. R., and D. B. Olson, 1978: Gulf Stream Ring coalescence with the Gulf Stream off Cape Hatteras. Science, 202, 971-972.

Worthington, L. V., 1959: The $18^{\circ}$ water in the Sargasso Sea. Deep-Sea Res., 5, 297-305.

1977: Intensification of the Gulf Stream after the winter of 1976-1977. Nature, 270, 415-417. 
FOR UNCLASSIFIED TECHNICAL REPORTS, REPRINTS, AND FINAL REPORTS

PUBLISHED BY OCEANOGRAPHIC CONTRACTORS

OF THE OCEAN SCIENCE AND TECHNOLOGY DIVISION

OF THE OFFICE OF NAVAL RESEARCH

(REVISED NOVEMBER 1978)

1 Deputy Under Secretary of Defense (Research and Advanced Technology)

Military Assistant for Environmental Science Room 3D129

Washington, D.C. 20301

Office of Naval Research

800 North Quincy Street

Arlington, VA 22217

3 ATTN: Code 483

1 ATTN: Code 460

2 ATTN: 102B

1 CDR J. C. Harlett, (USN)

ONR Representative

Woods Hole Oceanographic Inst.

Woods Hole, MA 02543

Commanding Officer

Naval Research Laboratory

Washington, D.C. 20375

6 ATTN: Library, Code 2627
12 Defense Documentation Center Cameron Station

Alexandria, VA 22314

ATTN: DCA

Commander

Naval Oceanographic Office NSTL Station

Bay St. Louis, MS 39522

ATTN: Code 8100

ATTN: Code 6000

ATTN: Code 3300

1 NODC/NOAA

Code D781

Wisconsin Avenue, N.W. Washington, D.C. 20235 
UNCLASSIFIED $\quad 11 / 80$

SECURITY CLASSIFICATION OF THIS PAGE (When Dace Entered)

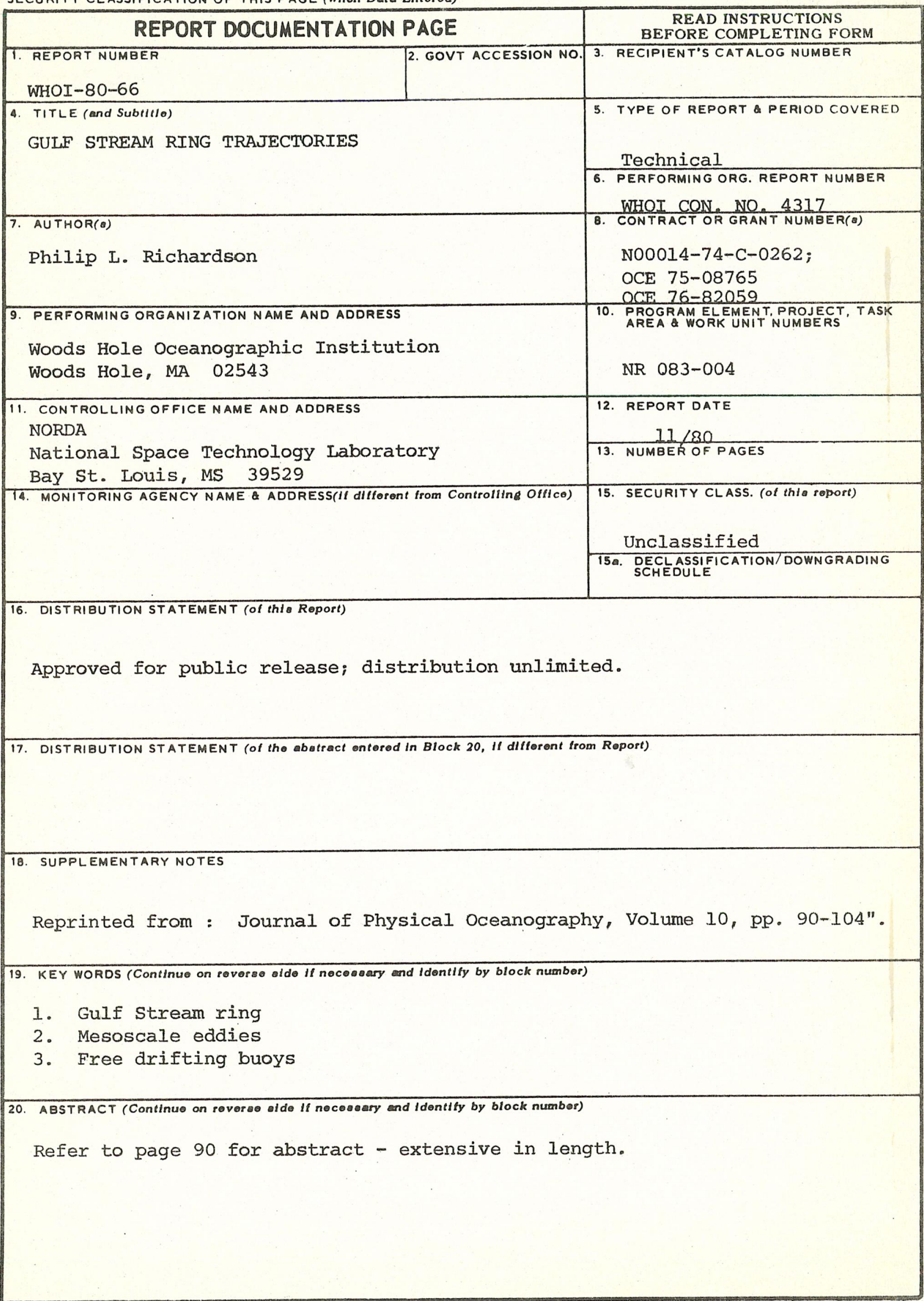




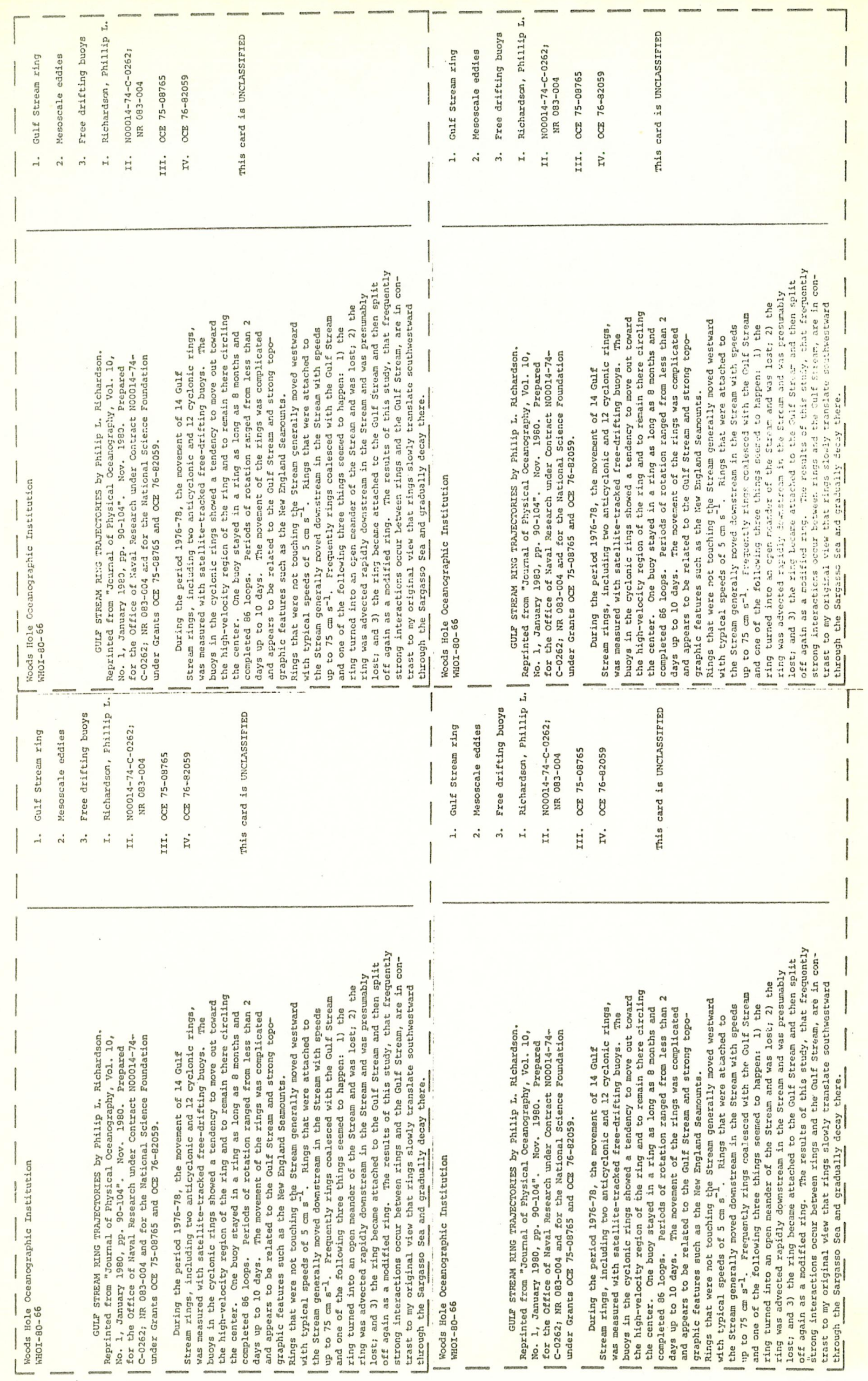

